\title{
Treatment Satisfaction in Patients with Diabetes Mellitus Type 1 Treated with Intensified Insulin Therapy with Insulin Analogues
}

\author{
Saša Radenković, Milena Velojić Golubović, Danijela Radojković, Vojislav Ćirić, \\ Radivoj Kocić \\ ${ }^{1}$ University of Niš, Faculty of Medicine, Niš, Serbia \\ ${ }^{2}$ Clinic for Endocrinology, Diabetes and Metabolic Disease, University Clinical Center Niš, Niš, Serbia
}

SUMMARY

The outcome of diabetes treatments can and should be evaluated through the patients' treatment satisfaction. The aim of this study was to examine the patients' satisfaction with the therapy with human insulin analogues compared with previous treatment with human insulin.

We evaluated patient satisfaction in patients with T1DM in our institution who were currently on IIT with human insulins. We performed testing with standard World Health Organization Diabetes Treatment Satisfaction Questionnaire (WHO DTSQ) before and after the therapy with insulin analogs.

The overall DTSQ score in forty-nine patients after the third month of therapy and after the sixth month of therapy is higher than before the initiation of therapy $(p<0.001)$. The results of the responses on the perception of hyperglycaemia were lower after three months of therapy $(p<0.05)$ and after the six months of treatment than before the onset of therapy $(p<0.01)$. There were no differences in the perception of hypoglycaemia after three months; however, perception of hypoglycaemia after the sixth month of treatment was lower than before the onset of therapy $(p<0.001)$ and compared to the score after the third month of therapy $(\mathrm{p}<0.01)$.

Therapy of T1DM patients with insulin analogue aspart over three months led to an increase in satisfaction with therapy and a reduction of the perception of hyperglycaemia. Therapy of T1DM patients with insulin analogues (aspart and glargine) over three months led to an increase in satisfaction with therapy and a reduction of the perception of both hyperglycaemia and hypoglycamia.

Key words: type 1 diabetes, treatment satisfaction, Diabetes Treatment Satisfaction Questionnaire, intensified insulin therapy, insulin analogues

Corresponding author:

Saša Radenković

e-mail: doktor.sasa@gmail.com 


\section{INTRODUCTION}

Diabetes mellitus (DM) is a metabolic disorder with a high prevalence across the world. The chronic hyperglycaemia of diabetes causes damage of different organs, promoting development of the complications. Therefore, this chronic disease affects the quality of life negatively in various fields. Treating diabetes delays the onset and progression of vascular complications and that improves quality of life (QOL) of the people with diabetes (1).

According to all recommendations, the proposed modern insulin therapy in patients with type $1 \mathrm{DM}$ (T1DM) is the intensified insulin therapy (IIT) or multiple daily insulin injections (MDII). Intensified insulin therapy is a cornerstone for good glycaemic control and it provides (as documented in DCCT) a reduction of the risk of developing chronic vascular complications of diabetes. Therefore, almost all of diabetic patients with T1DM should be treated with the IIT (2).

The pharmacokinetic profile of the action of the human insulin products could not fully provide an insulin profile identical to the physiological one. Namely, after injection of human soluble insulin, its plasma concentration does not rise as fast and high as it does in healthy people and it also does not decrease to pre-meal values as fast after normalizing blood glucose as in healthy people. In short, the human insulin of rapid and short action has an effect that is neither fast enough nor short enough. On the other hand, basal insulinisation (which in healthy subjects has a fairly uniform level over 24 hours) cannot be imitated fully using human insulin preparations (NPH or Lente insulins). Plasma insulin levels rise after the injection of human insulin gradually from a level that is initially insufficient and then reaches the maximum effect (i.e. peak) when the level of insulin in plasma is usually too high and then its concentration in plasma decreases again, often to a level that is insufficient before the next injection of human insulin preparation. In short, human insulin preparations have no effect that is long enough and more importantly that is uniform enough for 24 hours $(3,4)$.

The end of the $20^{\text {th }}$ century was marked by the introduction of human insulin analogue therapy. With improved pharmacokinetics, insulin analogues provide better and more physiological profile of the effect of insulin. Fast-acting analogues have provided much better compensation for pre-meal bolus in- sulin in IIT (5). Since year 2000, long-acting insulin analogues have also been available, which has enhanced basal insulinisation in IIT, and according to the results they provide the possibility of achieving better glycoregulation with less hypoglycaemia and a smaller increase in body weight compared to human insulin in IIT $(6,7)$. Thus, modified insulins with their superior pharmacokinetic profile can provide better control of blood glucose, both fasting and postprandial $(8,9)$. There is evidence that in IIT the combination of insulin glargine as basal insulin with fast-acting insulin analogues before meals provides benefits in relation to the IIT with human insulins (10).

To evaluate diabetes treatments, we use $\mathrm{HbA1c}$ levels, but it is also important to evaluate the patients' treatment satisfaction and quality of life (QOL). Patient satisfaction is important in chronic diseases like DM (11). Poor treatment satisfaction can lead to poor treatment compliance, which consequently leads to worsening of treatment results.

The Diabetes Treatment Satisfaction Questionnaire (DTSQ) is a questionnaire used to assess patients' satisfaction with their diabetes treatment (12). DTSQ is composed of eight questions, each of which is scored by patients on a scale ranging from zero (e.g., "very dissatisfied", "very inconvenient") to six (e.g., "very satisfied", "very convenient"). DTSQ is widely used because it is able to assess treatment satisfaction irrespective of the treatment methods used, including dietary therapy, therapy with oral hypoglycaemic agents or insulin therapy and it is relatively easy for the patients to answer the simple eight questions. DTSQ has been translated into more than 100 languages and is widely used in many countries since it is internationally validated and officially approved by the World Health Organization (WHO) and the International Diabetes Federation (IDF) $(12,13)$.

The aim of this study was to examine the patients' satisfaction with the therapy with human insulin analogues compared with the satisfaction with previous treatment with human insulins.

\section{PATIENTS AND METHODS}

This prospective study used a comparison of data obtained in patients with T1DM from the Clinic for Endocrinology, Diabetes and Metabolic Diseases of the University Clinical Center Niš. Subjects were patients with a diagnosis of T1DM and at least one 
year of duration of illness and insulin therapy, currently on IIT with human insulins. Patients were first followed with the existing therapy for one month. After that, the fast-acting insulin analogue (insulin aspart) was introduced to patients instead of human soluble insulin. On the day of introduction into the therapy of rapid-acting analogue of human insulin, the patients were examined (Visit $1-\mathrm{V} 1$ ). After a period of three months, long-acting insulin analogue (insulin glargine) was introduced instead of NPH human insulin. On the day of introduction into the therapy of long-acting analogue, the patients were examined (Visit 2-V2). After a period of three months with this therapy, the patients were examined (Visit 3 - V3).

Patients were tested with the standard $\mathrm{WHO}$ DTSQ (13) questionnaire before and after the therapy (on all three visits). The outcome was a change in the Diabetes Treatment Satisfaction Questionnaire (DTSQ) scores from Visit 1 to Visits 2 and 3.

The DTSQ covers eight items with regard to the diabetes treatment over the past weeks and measures overall satisfaction, convenience, flexibility, understanding of diabetes, willingness to recommend current treatment to others and willingness to continue the current treatment. Each item is rated on a 7-point scale with a score ranging from 0 (i.e., very dissatisfied) to 6 (i.e., very satisfied). DTSQ items two and three assess glycaemic control rather than satisfaction (perceived hyperglycaemia and perceived hypoglycaemia). These items are rated dif- ferently: 0 reflects "never" and 6 reflects "most of the time".

All scores except those from DTSQ items 2 and 3 (the scores of the six items of the DTSQ) are added up to produce a DTSQ total score (overall treatment satisfaction score ranging from 0 - 36). Higher scores on the DTSQ total score indicate higher treatment satisfaction and lower scores indicate lower treatment satisfaction. Perceived frequency of hyperglycaemia and hypoglycaemia were assessed in the DTSQ which were rated on a scale of 6 ("most of the time") to 0 ("never"); therefore, for these two items lower scores indicate higher treatment satisfaction (13).

Statistical analysis was performed using SPSS package (SPSS program version 15.0). The results of the statistical analysis are shown in the table. Scores are represented by mean values and standard deviations (SD) and median. Wilcoxon Signed Ranks Test was used to test the statistical significance of the differences in parameter values. $\mathrm{P}<0.05$ was considered as statistically significant.

\section{RESULTS}

Data were analyzed in forty-nine patients $(27$ male $-55.10 \%), 29.94 \pm 4.98$ years old (mean \pm SD), with established diagnosis of T1DM and at least one year of duration of illness and insulin therapy and who were currently on IIT with human insulins (average duration of T1DM was $13.94 \pm 7.70$ years).

Table 1. Results of a DTSQ score for assessing satisfaction with therapy before and after the introduction of insulin analogues in the therapy

\begin{tabular}{|c|c|c|c|c|c|c|c|c|c|}
\hline & \multicolumn{2}{|c|}{ V1 } & \multirow{2}{*}{\begin{tabular}{|c|}
$p$ Value \\
(V1 vs V2)
\end{tabular}} & \multicolumn{2}{|l|}{$\mathrm{V} 2$} & \multirow{2}{*}{$\begin{array}{l}\mathrm{p} \text { Value } \\
\text { (V2 vs V3) }\end{array}$} & \multicolumn{2}{|l|}{ V3 } & \multirow{2}{*}{\begin{tabular}{|l}
$\mathrm{p}$ Value \\
(V1 vs V3)
\end{tabular}} \\
\hline & Mean \pm SD & median & & Mean \pm SD & median & & Mean \pm SD & median & \\
\hline $\begin{array}{l}\text { DTSQ total } \\
\text { score }\end{array}$ & $24.43 \pm 4.39$ & 25 & $\mathrm{P}<0.001$ & $27.96 \pm 5.10$ & 28 & $P=0.08$ & $29.78 \pm 5.18$ & 30 & $\mathrm{P}<0.001$ \\
\hline $\begin{array}{l}\text { DTSQ2: } \\
\text { perceived } \\
\text { hypergly- } \\
\text { caemia }\end{array}$ & $1.69 \pm 1.34$ & 2 & $\mathrm{P}<0.05$ & $1.41 \pm 1.15$ & 2 & $\mathrm{P}<0.05$ & $0.98 \pm 0.97$ & 1 & $\mathrm{P}<0.01$ \\
\hline $\begin{array}{l}\text { DTSQ3: } \\
\text { perceived } \\
\text { hypogly- } \\
\text { caemia }\end{array}$ & $1.63 \pm 1.20$ & 2 & $P=0.2$ & $1.33 \pm 1.18$ & 1 & $\mathrm{P}<0.01$ & $0.69 \pm 0.80$ & 1 & $\mathrm{P}<0.001$ \\
\hline
\end{tabular}

SD-standard deviation; V1-Visit 1; V2-Visit 2; V3-Visit 3; DTSQ-Diabetes Treatment Satisfaction Questionnaire; DTSQ2DTSQ item 2; DTSQ3-DTSQ item 3 
The results of an evaluation with a DTSQ questionnaire for assessing satisfaction with therapy before and after the introduction of insulin analogues in the therapy are shown in Table 1.

The overall score on the six questions of the questionnaire (all questions except questions about the perception of hypoglycaemia and hyperglycaemia, each question from 0 to 6 points, total score from 0 to 36 maximum) after the third month of therapy and after the sixth month of therapy was statistically significantly higher than before the initiation of therapy $(27.96 \pm 5.10$ vs. $24.43 \pm 4.39$ and $29.78 \pm 5.18$ vs. $24.43 \pm 4.39$, respectively; $p<0.001$ ). There is also the difference between overall scores of the questionnaire after the sixth month of therapy and after the third month of therapy, but it is borderline insignificant $(29.78 \pm 5.18$ vs. $27.96 \pm 5.10$; $\mathrm{p}=0.08)$.

The results of the responses to the question on the perception of hyperglycaemia were significantly lower after three months of therapy, that is after the introduction of insulin aspart in relation to the score at the start of treatment $(1.41 \pm 1.15$ vs. $1.69 \pm 1.34$; $p$ $<0.05)$. The results of the responses to the question on the perception of hyperglycaemia after the sixth month of treatment were statistically lower than before the onset of therapy $(0.98 \pm 0.97$ vs. $1.69 \pm 1.34$; $\mathrm{p}<0.01)$ and also compared with the results after the third month of therapy $(0.98 \pm 0.97$ vs. $1.41 \pm 1.15$; $\mathrm{p}<$ 0.05).

There were no differences in the perception of hypoglycaemia after three months with the introduction of only fast insulin analogue. The results of the answers to the question on the perception of hypoglycaemia after the sixth month of treatment were statistically lower than before the onset of the therapy $(0.69 \pm 0.80$ vs. $1.63 \pm 1.20 ; p<0.001)$ and compared to the score after the third month of therapy $(0.69 \pm 0.80$ vs. $1.33 \pm 1.18 ; \mathrm{p}<0.01)$.

\section{DISCUSSION}

We have evaluated patient satisfaction using DTSQ in patients with T1DM. A large number of studies have shown that diabetic patients who use insulin analogues describe greater satisfaction with therapy than those using human insulin (14).

In a prospective, multicenter, randomized, open-label, parallel-group study involving 423 patients with T1DM on basal bolus therapy, par- ticipants received either insulin aspart or human insulin as bolus insulin. Treatment satisfaction was assessed using the World Health Organization Diabetes Treatment Satisfaction Questionnaire - WHO DTSQ (15). The overall score for the hyperglycaemia perceptions issue was lower in the group treated with insulin aspart indicating that these patients felt that an unacceptably high level of glycaemia was less pronounced than in patients treated with human insulin $(p=0.005)$. A group of patients treated with insulin aspart also noted a higher degree of flexibility compared to those treated with human insulin $(\mathrm{p}=0.022)$.

In a prospective six-month study conducted in 88 centers in eight European countries, 1,070 adult patients with T1DM were randomized to a ratio of 2:1 to insulin aspart or human insulin therapy before meals, all with NPH insulin as basal insulin. Satisfaction with the therapy (expressed through the results of the WHO DTSQ questionnaire) was significantly higher in the group using insulin aspart (difference in score compared to the initial 2.3 points; $\mathrm{p}<0.001$ ) (16).

A third study that compared quality of life and had a crossover design included 468 patients with T1DM who were three months on therapy with either insulin lispro or regular human insulin as part of the basal-bolus regimen of insulin therapy. The satisfaction with treatment in insulin-treated lispro patients increased significantly compared to the human insulin treatment period $(\mathrm{p}<0.001)$. The score for therapy flexibility was significantly higher with insulin lispro $(p=0.001)(17)$.

We tested our patients with a standard questionnaire (WHO DTSQ). The overall score on satisfaction with therapy was significantly higher after the first three months of therapy compared to the score before the start of the therapy with the analogues, and after six months the total score was even higher, i.e. significantly higher than the score before the start of the therapy with the analogues, but without statistically significant difference in relation to the score after the first three months of therapy. This is in accordance with previously reported data that diabetic patients who use insulin analogues describe greater satisfaction with therapy than those using human insulin. The difference is present with every introduction of insulin analogues in therapy and show that patients have higher treatment satisfaction with new therapy (both with rapid and long- 
acting insulin analogues).

The result for the perception of hyperglycaemia is significantly lower after three months of therapy (after the introduction of insulin aspart) in relation to the score at the start of treatment. These results indicate that patients themselves also perceive the improvement of blood glucose control with better prandial insulin. The perception of hyperglycaemia is significantly lower after six months of therapy, after the introduction of insulin glargine, in relation to the score at the start of treatment and after the third month. This proves that the combination of insulin glargine as a basal insulin with fast-acting insulin analogues before meals provides further benefits for the patients in relation to the IIT with human insulins and that patients feel reduced burden of hyperglycaemia after switching to insulin analogues.

A similar improvement in the perception of hypoglycaemia was also shown. A significantly lower score was recorded at the end of the study (after six months) compared with the score at the start of treatment and also compared with the score after three months of therapy. There were no differences in the perception of hypoglycaemia after three months of therapy with the introduction of only fast insulin analogues. These results indicate that patients perceive the improvement of blood glucose control and the reduction in the number of hypoglycaemia with the treatment with long-acting insulin analogues. Reduction of number and severity of hypoglycaemia episodes in patients after starting the therapy with insulin glargine as a basal insulin is often emphasized and this results confirm that our patients also notice this reduction (18).

\section{CONCLUSION}

Therapy of T1DM patients with insulin analogue insulin aspart in intensified insulin therapy (with basal NPH insulin) over three months led to a significant increase in satisfaction with therapy and a significant reduction of the perception of hyperglycemia.

Therapy of T1DM patients with insulin analogues (insulin aspart and insulin glargine in intensified insulin therapy) over three months led to a significant increase in satisfaction with therapy and a significant reduction of the perception of both hyperglycemia and hypoglycaemia.

\section{References}

1. Boyle JP, Honeycutt AA, Narayan KM et al. Projection of diabetes burden through 2050. Diabetes Care 2001;24(11):1936-40. https://doi.org/10.2337/diacare.24.11.1936

2. Diabetes Control and Complications Trial Research Group. The effect of intensive treatment of diabetes on the development and progression of long-term complications in insulin-dependent diabetes mellitus. N Engl J Med 1993;329(14):977-86.

https://doi.org/10.1056/NEJM199309303291401
3. Home PD. Intensive insulin therapy in clinical practice. Diabetologia 1997;40 Suppl 2:S83-7. https://doi.org/10.1007/s001250051412

4. DeWitt DE, Hirsch IB. Outpatient insulin therapy in type 1 and type 2 diabetes mellitus: scientific review. JAMA 2003;289(17):2254-64. https://doi.org/10.1001/jama.289.17.2254

5. Raskin P, Guthrie RA, Leiter Let al. Use of insulin aspart, a fast-acting insulin analog, as the mealtime insulin in the management of patients 
with type 1 diabetes. Diabetes Care 2000;23:583-8. https://doi.org/10.2337/diacare.23.5.583

6. Ashwell SG, Amiel SA, Bilous RW et al. Improved glycaemic control with insulin glargine plus insulin lispro: a multicentre, randomized, crossover trial in people with type 1 diabetes. Diabet Med 2006;23:285-92.

https://doi.org/10.1111/j.1464-5491.2005.01781.x

7. Porcellati F, Rossetti P, Pampanelli S et al. Better long-term glycaemic control with the basal insulin glargine as compared with NPH in patients with type 1 diabetes mellitus given meal-time lispro insulin. Diabet Med 2004;21:1213-20.

https://doi.org/10.1111/j.1464-5491.2004.01323.x

8. Hirsch IB. Insulin analogues. N Engl J Med 2005;352(2):174-83.

https://doi.org/10.1056/NEJMra040832

9. Bolli GB, Di Marchi RD, Park GDet al. Insulin analogues and their potential in the management of diabetes mellitus. Diabetologia 1999;42(10):1151-67. https://doi.org/10.1007/s001250051286

10. Garg S, Moser E, Dain MP, Rodionova A. Clinical experience with insulin glargine in type 1 diabetes. Diabetes Technol Ther 2010;12(11):835-46.

https://doi.org/10.1089/dia.2010.0135

11. Biderman A, Noff E, Harris SBet al. Treatment satisfaction of diabetic patients: what are the contributing factors? Fam Pract 2009;26(2):102-8. https://doi.org/10.1093/fampra/cmp007

12. Bradley C, Gamsu DS. Guidelines for encouraging psychological well-being: report of a Working Group of the World Health Organization Regional Office for Europe and International Diabetes Federation European Region St Vincent
Declaration Action Programme for Diabetes. Diabet Med 1994;11(5):510-6. https://doi.org/10.1111/j.1464-5491.1994.tb00316.x

13. Bradley C, Speight J. Patient perceptions of diabetes and diabetes therapy: assessing quality of life. Diabetes Metab Res Rev 2002;18 Suppl 3:S64-9. https://doi.org/10.1002/dmrr.279

14. Sheldon B, Russell-Jones D, Wright J. Insulin analogues: an example of applied medical science. Diabetes Obes Metab 2009;11(1):5-19. https://doi.org/10.1111/j.1463-1326.2008.01015.x

15. Tamás G, Marre M, Astorga Ret al. Insulin Aspart Study Goup. Glycaemic control in type 1 diabetic patients using optimised insulin aspart or human insulin in a randomised multinational study. Diabetes Res Clin Pract 2001;54(2):105-14. https://doi.org/10.1016/S0168-8227(01)00262-5

16. Home PD, Lindholm A, Riis A; European Insulin Aspart Study Group. Insulin aspart vs. human insulin in the management of long-term blood glucose control in Type 1 diabetes mellitus: a randomized controlled trial. Diabet Med 2000;17(11):762-70.

https://doi.org/10.1046/j.1464-5491.2000.00380.x

17. Kotsanos JG, Vignati L, Huster W et al. Healthrelated quality-of-life results from multinational clinical trials of insulin lispro. Assessing benefits of a new diabetes therapy. Diabetes Care 1997;20(6):948-58.

https://doi.org/10.2337/diacare.20.6.948

18. Bradley C, Gilbride CJ. Improving treatment satisfaction and other patient-reported outcomes in people with type 2 diabetes: the role of oncedaily insulin glargine. Diabetes Obes Metab 2008;10 Suppl 2:50-65.

https://doi.org/10.1111/j.1463-1326.2008.00871.x 


\title{
Zadovoljstvo terapijom kod bolesnika sa dijabetesom melitusom tip 1 lečenim intenziviranom insulinskom terapijom analozima insulina
}

\author{
Saša Radenković, Milena Velojić Golubović, Danijela Radojković, Vojislav Ćirić, \\ Radivoj Kocić \\ ${ }^{1}$ Universitet $u$ Nišu, Medicinski Fakultet, Niš, Srbija \\ ${ }^{2}$ Univerzitetski klinički centar Niš, Klinika za endokrinologiju, dijabetes i bolesti metabolizma, Niš, Srbija
}

\section{SAŽETAK}

Ishodi lečenja dijabetesa mogu i treba da se procenjuju kroz analize zadovoljstva bolesnika terapijom. Cilj ove studije bio je da se ispita zadovoljstvo bolesnika terapijom analozima insulina $u$ poređenju sa prethodnim tretmanom humanim insulinima.

Procenjivali smo zadovoljstvo terapijom bolesnika sa T1DM, na našoj klinici, koji su aktuelno bili na IIT humanim insulinima. Bolesnici su pre i nakon terapije ispitani standardnim upitnikom za procenu zadovoljstva terapijom (The World Health Organization Diabetes Treatment Satisfaction Questionnaire WHO DTSQ).

Ukupni DTSQ skor naših četrdeset devet bolesnika na šest pitanja iz upitnika, nakon trećeg meseca terapije i nakon šestog meseca terapije veći je nego pre početka terapije $(p<0,001)$. Rezultati odgovora na pitanje o percepciji hiperglikemije bili su niži nakon tri meseca terapije $(p<0,05)$ i nakon šest meseci lečenja, nego pre početka terapije $(\mathrm{p}<0,01)$. Nije bilo razlika u percepciji hipoglikemija nakon tri meseca, ali je percepcija hipoglikemija nakon šestog meseca lečenja bila niža, nego pre početka terapije $(p<0,001)$ i u poređenju sa percepcijom nakon trećeg meseca terapije $(\mathrm{p}<0.01)$.

Terapija bolesnika sa T1DM insulinskim analogom aspart tokom tri meseca dovela je do povećanja zadovoljstva terapijom i smanjenja percepcije hiperglikemije. Terapija bolesnika sa T1DM insulinskim analozima (aspart i glargin) tokom tri meseca dovela je do povećanja zadovoljstva terapijom i smanjenja percepcije i hiperglikemije i hipoglikemija.

Ključne reči: dijabetes melitus tip 1, zadovoljstvo terapijom, Diabetes Treatment Satisfaction Questionnaire, intenzivirana insulinska terapija, analozi insulina 